\title{
Multi-susceptibility genes associated with the risk of the development stages of esophageal squamous cell cancer in Feicheng County
}

Qing Da $\mathrm{Li}^{1 \dagger}$, Hao $\mathrm{Li}^{2^{*+}}$, Mei Shu Wang ${ }^{3+}$, Tao Yu Diao ${ }^{4}$, Zhi Ying Zhou ${ }^{5}$, Qiang Xue Fang ${ }^{6}$, Fang Yan Yang ${ }^{7}$ and Qing Hui Li ${ }^{4}$

\begin{abstract}
Background: The purpose of this study was to evaluate the association of multi-genotype polymorphisms with the stepwise progression of esophageal squamous cell cancer (ESCC) and the possibility of predicting those at higher risk.
\end{abstract}

Methods: A total of 1,004 subjects were recruited from Feicheng County, China, between Jan. 2004 and Dec. 2007 and examined by endoscopy for esophageal lesions. These subjects included 270 patients with basal cell hyperplasia (BCH), 262 patients with esophageal squamous cell dysplasia (ESCD), 226 patients with ESCC, and 246 controls with Lugol-voiding area but diagnosed as having normal esophageal squamous epithelial cells by histopathology. The genotypes for CYP2E1 G1259C, hOGG1 C326G, MTHFR C677T, MPO G463A, and ALDH2 allele genes were identified in blood samples collected from all participants.

Results: The alleles ALDH2 and MTHFR C677T were critical for determining individual susceptibility to esophageal cancer. Compared to the ALDH $1 * 1$ genotype, the ALDH 2*2 genotype was significantly associated with increased risks of $\mathrm{BCH}, \mathrm{ESCD}$, and ESCC. However, the $\Pi$ genotype of MTHFR C677T only increased the risk of ESCC. Further analysis revealed that the combination of the high-risk genotypes $2 * 2 / 1 * 2$ of ALDH 2 and TT/TC of MTHFR C677T increased the risk of BCH by 4.0 fold, of ESCD by 3.7 fold, and ESSC by 8.72 fold. The generalized odds ratio $\left(\mathrm{OR}_{\mathrm{G}}\right)$ of the two combined genotypes was 1.83 (95\%Cl: 1.55-2.16), indicating a strong genetic association with the risk of carcinogenic progression in the esophagus.

Conclusions: The study demonstrated that the genotypes ALDH2*2 and MTHFR 677TT conferred elevated risk for developing esophageal carcinoma and that the two susceptibility genotypes combined to synergistically increase the risk.

\section{Background}

Esophageal cancer is the fourth most common cause of cancer-related death in China. Esophageal cell carcinoma (ESCC) is by far the most common subtype of esophageal cancer, followed distantly by adenocarcinoma, which accounts for less then $3 \%$ of all esophageal cancers in high incidence areas of China [1].

The pathogenesis of ESCC is thought to include a stepwise progression from basal cell hyperplasia $(\mathrm{BCH})$ to

\footnotetext{
*Correspondence: haoli2003611@163.com

† Contributed equally

${ }^{2}$ Department of Hematology of Tumor Center, Qilu Hospital of Shandong

University, 107\# Wenhuaxi Road, Jinan, 250012, China

Full list of author information is available at the end of the article
}

low-grade dysplasia (LGD), high-grade dysplasia (HGD), carcinoma in situ, and finally invasive carcinoma. Japanese and Chinese pathologists prefer to classify LGD as mild-dysplasia or moderate-dysplasia, and HGD as severe-dysplasia. They defined esophageal dysplasia as a precancerous lesion of ESCC [2-5]. Epidemiological studies indicated that esophageal dysplasia was associated with a significantly increased risk of developing invasive ESCC [6-10].

Endoscopic screening with the Lugol dye method combined with pathologic evaluation has proven useful in screening for early esophageal cancer and in ascertaining the different stages of esophageal carcinogenesis 
in high-incidence areas [11]. This test is relatively expensive, however, and patients may experience pain and discomfort, so only a small percentage of the population may be willing to participate in this testing program. With the development of molecular techniques, however, it is now possible to employ useful biomarkers to identify subjects at high-risk who should receive this pathological screening test.

Recent studies have suggested that a variety of genes may be associated with susceptibility to ESCC. These include the aldehyde dehydrogenase-2 gene ( $A L D H 2)$ [12-14], the methylene tetrahydrofolate reductase gene (MTFHR) [15-17], cytochrome P450 2E1 (CYP2E1) $[18,19]$, myeloperoxidase gene $(M P O)[20,21]$, and the human 8-oxoguanine glycosylase 1 gene (hOGG1) [22]. Indeed, there was a weak association between each of these five susceptibility genes alone and esophageal cancer. It is unclear, however, whether a combination of these susceptibility genes could be employed as useful biomarkers to predict significantly elevated risk for ESCC.

In the present study, we developed a program for evaluation of esophageal lesions using endoscopic screening with the Lugol dye method. The screening ran from Jan. 2005 to Dec. 2007 in Feicheng County, China. In addition to endoscopic evaluation for various types of esophageal lesions, the multi-genotype polymorphisms of CYP2E1 G1259C, hOGG1 C326G, MTHFR C677T, MPO G463A, and $A L D H 2$ genes were identified for each individual subject. Therefore, this program provided a valuable opportunity to first examine the potential association between a specific combination of genotypes and the carcinogenic progression during ESCC, and then to evaluate the possibility of using the genotype combination as a biomarker to predict ESCC risk.

\section{Methods}

\section{Study subjects}

The human subject protocol for this study was approved by the Ethics Committee of the Medical Faculty of the Shandong Academy of Medical Sciences. Written informed consent was obtained from all participants.

For subject recruitment, a questionnaire interview was first conducted to collect information, such as sociodemographic characteristics, alcohol intake, tobacco use, and family history of esophageal carcinoma. Then, a routine physical examination, electrocardiogram, and abdomen ultrasound were provided to all candidates. Those who had liver diseases, cardiovascular diseases, lung diseases, or head-and-neck diseases were excluded for further consideration. All candidate subjects were given an endoscopic staining examination with $1.2 \%$ iodine solution for evaluation of esophageal lesions. Furthermore, for persons with a non-staining area of the mucosa, random 4-quadrant biopsy specimens were obtained at $2-\mathrm{cm}$ intervals.
Specimens were processed by the standard procedure [5] and histopathological diagnoses were made by two independent pathologists.

A total of 10125 persons took part in the endoscopic staining examination. Of these patients, 1364 had a nonstaining area of the mucosa and were diagnosed by histopathologic analysis of biopsy tissue. These patients included 280 with basal cell hyperplasia (BCH), 577 with esophageal squamous cell dysplasia (ESCD), 94 with esophageal squamous cell cancer (ESCC) at early stage, and 267 controls with normal esophageal squamous epithelial cells. We randomly selected $50 \%$ of the ESCD for further study using the program SPSS. Another 146 patients with ESCC were referred from the Hospital of Feicheng County. In total, 1004 subjects with pathological data were available for the analysis, including 270 patients with $\mathrm{BCH}$, 262 patients with ESCD, 226 patients with ESCC, and 246 controls with Lugol-voiding area but diagnosed as normal by histopathology of esophageal squamous epithelial cells. For genotype assays, 5-8 ml of blood were collected from each participant in a sterile cryogenic vial and stored at $-70{ }^{\circ} \mathrm{C}$ until processed.

The sample size was calculated by the Power 3.0 software (http://dceg.cancer.gov/bb/tools/power). We recalculated the sample size based on the following parameters: design: case-control study; case: control $=1: 1$; probability of esophageal cancer $=0.001$ for the aged $40-69$; observed minor allele frequency 0.1-0.25; a moderate genetic risk effect $(\mathrm{OR}=1.2-1.3)$; $\mathrm{P}$-value $=0.05 ; 1-\beta=0.8$; additive effect model $\mathrm{OR}=3.0$ of two genes exposure, the sample size $=265$. According to the actual sample sizes in the study, the posterior powers $(1-\beta)$, were $0.735,0.796,0.808$ and 0.769 for the above four groups of ESCC, ESLD, BCH and controls, respectively.

\section{PCR-RFLP Polymorphism for MTHFR C677T, MPO G463A and CYP2E1 G1259C}

The PCR reaction was carried out in gradient PCR instrument (Eppendorf, Germany). The reaction mixture contained $25 \mathrm{ng}$ DNA, $10 \mathrm{mM}$ dNTP $0.5 \mu \mathrm{l}, 10 \times$ PCR Buffer $2.5 \mu \mathrm{l}, 10 \mathrm{uM}$ of each primer (Table 1 ) and 0.5 units of Taq DNA polymerase with the buffer $(20 \mathrm{mmol} / \mathrm{L}$ Tris- $\mathrm{HCl}$, $\mathrm{pH} 8.4 ; 50 \mathrm{mmol} / \mathrm{L} \mathrm{KCl}$ ) in a volume of $25 \mu \mathrm{l}$.

PCR conditions were $95^{\circ} \mathrm{C}$ for minutes, followed by 35 cycles of $95^{\circ} \mathrm{C}$ for 60 seconds optimal annealing temperature $\times{ }^{\circ} \mathrm{C}$ (Table 1 ) for 60 seconds and $72^{\circ} \mathrm{C}$ for 60 seconds followed by a final extension step of $72^{\circ} \mathrm{C}$ for 7 minutes.

The $5 \mu \mathrm{l}$ PCR product of MTHFR C677T gene was digested by a HinfI restriction enzyme. Digestion products were visualized after electrophoresis on a $3 \%$ agarose gel with ethidium bromide. Wild types $(677 \mathrm{CC})$ produced a single band at 198bp. Heterozygotes (677CT) produced 198,175 , and 23bp fragments. Homozygous mutants (677TT) produced 175 and 23bp fragments [16]. 
Table 1 PCR conditions for genotypes of test DNA genes in the study

\begin{tabular}{|c|c|c|c|}
\hline Gene & Primer sequence & Annealing & Restriction enzyme \\
\hline $\begin{array}{l}\text { MTHFR } \\
\text { C677T }\end{array}$ & $\begin{array}{l}\text { F: 5'-TGA AGG AGA AGG TGT CTG CGG GA-3' } \\
\text { R: 5'-AGG ACG GTG CGG TGA GAG TG-3' }\end{array}$ & $62^{\circ} \mathrm{C}$ & Hinf I \\
\hline $\begin{array}{l}\text { CYP2E1 } \\
\text { G1259C }\end{array}$ & $\begin{array}{l}\text { F: 5'-CCA GTC GAG TCT ACA TTG TCA-3' } \\
\text { R: 5'-TTC ATT CTG TCT TCT AAC TGG-3' }\end{array}$ & $55^{\circ} \mathrm{C}$ & Pstl \\
\hline $\begin{array}{l}\text { hOGG1 } \\
\text { C326G }\end{array}$ & $\begin{array}{l}\text { F: 5'-GGA AGG TGC TTG GGG AAT-3' } \\
\text { R: 5'-ACT GTC ACT AGT CTC ACC AG-3' }\end{array}$ & $58^{\circ} \mathrm{C}$ & Fnu4HI \\
\hline $\begin{array}{l}\text { MPO } \\
\text { G463A }\end{array}$ & $\begin{array}{l}\text { F: 5'-CGG TAT AGG CAC ACA ATG GTG AG-3' } \\
\text { R: 5'-GCA ATG GTT CAA GCG ATT C-3' }\end{array}$ & $62^{\circ} \mathrm{C}$ & Acil \\
\hline$A L D H 2$ & $\begin{array}{l}\text { F1: 5'-TCA TGC CAT GGC AAC TCC AGC-3' } \\
\text { R1: 5'-CCC ACA CTC ACA GTT TTC TCT TC-3' } \\
\text { F2: 5'-TAC GGG CTG CAG GCA TAC ACT A-3 } \\
\text { R2: 5'-TGA TCC CCA GCA GGT CCT GAA-3' }\end{array}$ & $60^{\circ} \mathrm{C}$ & \\
\hline
\end{tabular}

The PCR product of the MPO G463A gene digested by an AciI restriction enzyme yielding three possible genotypes which were defined by three distinct banding patterns: A/A 289 and 61bp fragments, A/G 289, 169, 120, and 6lbp fragments, and G/G 169, 120, and 6lbp fragments [20].

The PCR product of CYP2E1 G1259C gene was digested with PstI restriction endonuclease for 8 hours at $37^{\circ} \mathrm{C}$. Three possible genotypes were defined by three distinct banding patterns: C1/C1 410bp fragment, C1/ C2 410, 290 and 120 bp fragments, and C2/C2 290- and 120-bp fragments [18].

\section{PCR for $A L D H 2$}

The two pairs of primers shown in Table 1 were used in the PRC assay. F1 and R1 were used to amplify the $A L D H 2 * 1$ allele (296bp), and F2 and R2 to amplify the $A L D H 2 * 2$ allele (203bp). Two $25 \mu \mathrm{L}$ reaction tubes were needed for each specimen to amplify $A L D H 2 * 1$ (G) and $A L D H 2 \% 2$ (A) respectively, each containing $100 \mathrm{ng}$ DNA, $0.12 \mathrm{mmol} / \mathrm{L}$ dNTPs, $12.5 \mathrm{pmol} \mathrm{F1}$ (or R1) primer, 12.5 pmol F2 (or R2) primer, 0.5 U Taq polymerase, and $2.5 \mu \mathrm{L} 10 \times$ PCR buffer (containing $15 \mathrm{mmol} / \mathrm{L}$ $\mathrm{MgCl} 2$ ). The reaction tubes were heated to $95^{\circ} \mathrm{C}$ for 5 min followed by 30 cycles of $95^{\circ} \mathrm{C}$ for $60 \mathrm{~s}, 60^{\circ} \mathrm{C}$ for 60 $\mathrm{s}, 72^{\circ} \mathrm{C}$ for $60 \mathrm{~s}$, and $72^{\circ} \mathrm{C}$ for $45 \mathrm{~s}$, and then followed by a final extension of $5 \mathrm{~min}$ at $72^{\circ} \mathrm{C} .10 \mu \mathrm{L}$ PCR products were used in agarose gel electrophoresis and the electrophoresis result was photographed.

Two lanes were used for each specimen. If one showed 296 bp band and the other showed no band, the corresponding genotype was $A L D H 2 * 1 / 2 * 1$ (G/G); if one showed $296 \mathrm{bp}$ band and the other showed $203 \mathrm{bp}$ band, the corresponding genotype was $A L D H 2 * 1 / 2 * 2$ (G/A); and if one showed $203 \mathrm{bp}$ band and the other showed no band, the corresponding genotype was $A L D H 2 * 2 / 2 * 2$ (A/A) [23].

\section{PCR-SSCP analysis of hOGG1 C326G}

The PCR product was denatured with formamide at $95^{\circ} \mathrm{C}$ for $15 \mathrm{~min}$, quenched on ice, and loaded to polyacrylamide gels under several conditions. Visualization was performed with a silver stain kit (Wako, Osaka, Japan) as described [22]. The PCR product of hOGG1 C326G gene is digested by $F n u 4 H$ I on the polyacrylamide gels showed $\mathrm{C} / \mathrm{C}$ genotype is a band at 200bp, G/G genotype is a band at 100bp, and $\mathrm{C} / \mathrm{G}$ genotype is two bands at 200bp and $100 \mathrm{bp}$.

\section{Quality Control}

The genotypes of the DNA samples were identified without knowledge of the case or control status; $5 \%$ were randomly selected as a sample set of cases and controls that were genotyped by different investigators, and the reproducibility was $100 \%$. Each PCR procedure was performed with a blank control (without DNA template) and positive and negative controls. Cycle sequencing PCR product was performed to confirm the accuracy of this method of single-nucleotide polymorphisms (SNP) identification. When any of these controls failed, the PCR was repeated for the batch of samples.

\section{Statistical Analysis}

Pearson's Chi-Square and Kruskal-Wallis H tests were used to examine differences in sociodemographic characteristics, alcohol intake, tobacco use, and family history of esophageal cancer among the four diagnostic groups (Control, BCH, ESCD, and ESCC). Smoking index represents the number of cigarettes per day multiplied by the years of smoking. Alcohol drinking index equals the amount of alcohol consumed per month multiplied by drinking years. Allele frequencies were calculated using allele counting tests for Hardy-Weinberg equilibrium and were analyzed by the Chi-square test. Odds ratios (ORs) and $95 \%$ confidence interval $(95 \% \mathrm{CI})$ were calculated in the multinomial Logistic model after adjusting for the variables of age, smoking index, and drinking index.

An additional analysis based on the generalized odds ratio $\left(\mathrm{OR}_{\mathrm{G}}\right)$ was also performed. The $\mathrm{OR}_{\mathrm{G}}$ utilizes the complete genotype distribution and provides an estimate of the magnitude of the association between disease status and genotype [24]. The $\mathrm{OR}_{\mathrm{G}}$ and 95\%CI were 
calculated using the software "ORGGASMA" (downloaded from http://biomath.med.uth.gr). All other statistical analysis were performed using SPSS (version 15.0), and $P<0.05$ (two-sided) was accepted as statistically significant.

\section{Results}

\section{Characteristics of demographic and selected variables}

Demographic characteristics and selected variables are shown in Table 2. All seven variables, including gender, age, school years, income per year, smoking index, alcohol drinking status, and family history of esophageal cancer were significantly different among the four groups. Each variable also has a significant linear by linear association with the carcinogenic stages in transition from normal esophageal mucosa to carcinoma.

Table 2 Distribution of selected variables in the $\mathrm{BCH}$, ESCD, ESCC and controls

\begin{tabular}{|c|c|c|c|c|c|}
\hline Feature & $\begin{array}{c}\mathrm{BCH} \\
(\mathrm{n}=270)\end{array}$ & $\begin{array}{c}\text { ESCD } \\
(n=262)\end{array}$ & $\begin{array}{c}\text { ESCC } \\
(n=226)\end{array}$ & $\begin{array}{l}\text { Controls } \\
(n=246)\end{array}$ & $x^{2}\left(P^{c}\right)$ \\
\hline \multicolumn{6}{|c|}{ Gender (n,\%) } \\
\hline Male & 185(68.5) & $151(57.7)$ & $162(71.7)$ & $125(50.8)$ & 29.062 \\
\hline Female & $85(31.5)$ & $111(42.3)$ & $64(28.3)$ & $121(49.2)$ & $(<0.001)$ \\
\hline \multicolumn{6}{|l|}{ Age(yr) (n,\%) } \\
\hline$<50$ & $70(26.0)$ & $40(15.3)$ & $38(16.8)$ & $142(57.7)$ & 150.471 \\
\hline $50-$ & $138(51.1)$ & $138(52.7)$ & $102(45.1)$ & $66(26.8)$ & $(<0.001)$ \\
\hline$\geq 60$ & $62(23.0)$ & $84(32.1)$ & $86(38.1)$ & $38(15.4)$ & \\
\hline \multicolumn{6}{|c|}{ School $(y r)(n, \%)$} \\
\hline$\leq 6$ & $110(40.9)$ & $148(56.5)$ & $144(63.7)$ & $102(41.5)$ & 39.792 \\
\hline 9 & $129(47.7)$ & $92(35.1)$ & $72(31.9)$ & $120(48.8)$ & $(<0.001)$ \\
\hline$\geq 10$ & $31(11.5)$ & $22(8.4)$ & $10(4.4)$ & $24(9.8)$ & \\
\hline \multicolumn{6}{|c|}{ Income per year $(\$)(n, \%)$} \\
\hline$<150$ & $129(47.7)$ & $134(51.1)$ & $98(43.4)$ & $164(66.7)$ & 36.494 \\
\hline $150-$ & $117(43.4)$ & $92(35.1)$ & $94(41.6)$ & $66(26.8)$ & $(<0.001)$ \\
\hline$\geq 350$ & 24(8.9) & $36(13.7)$ & $34(15.0)$ & $16(6.5)$ & \\
\hline \multicolumn{6}{|c|}{ Smoking index ${ }^{a}(n, \%)$} \\
\hline None & $109(40.4)$ & $148(56.9)$ & $80(35.4)$ & $148(60.2)$ & 60.087 \\
\hline$<450$ & $63(23.4)$ & $38(14.6)$ & 36 (15.9) & 48(19.5) & $(<0.001)$ \\
\hline$\geq 450$ & $98(36.2)$ & $74(28.5)$ & $110(48.7)$ & $50(20.3)$ & \\
\hline \multicolumn{6}{|c|}{$\begin{array}{l}\text { Alcohol drinking Status }{ }^{b} \\
(n, \%)\end{array}$} \\
\hline None & $114(42.4)$ & $136(53.1)$ & $76(33.6)$ & $138(56.1)$ & 68.712 \\
\hline$<100$ & $43(16.0)$ & $44(17.2)$ & $32(14.2)$ & $62(25.2)$ & $(<0.001)$ \\
\hline$\geq 100$ & 112(41.6) & 76(29.7) & $118(52.2)$ & 46(18.7) & \\
\hline \multicolumn{6}{|c|}{$\begin{array}{l}\text { Family history of esophagus cancer } \\
(n, \%)\end{array}$} \\
\hline None & 231 (85.5) & $2021(77.1)$ & 190(84.1) & $222(90.2)$ & 17.027 \\
\hline yes & $39(14.5)$ & $60(22.9)$ & $36(15.9)$ & 24(9.8) & $(<0.001)$ \\
\hline
\end{tabular}

${ }^{a}$ smoking index $=$ cigarette/day $\times$ number of smoking years. ${ }^{b}$ alcohol drinking $\geq 100 \mathrm{~g} /$ day means heavy drinker. ${ }^{c} P$ : Chi-square test was for proportions among the four groups.

Abbreviations: $\mathrm{BCH}$, Basal cell hyperplasia; ESCD, esophageal squamous cell dysplasia; ESCC, Esophageal Squamous cell cancer.

\section{Associations of CYP2E1 G1259C, MPO G463A, MTHFR C677T, hOGG1 C326G, and ALDH2 genotypes with $\mathrm{BCH}$, ESCD, and ESCC}

The frequency distribution of CYP2E1 G1259C, $M P O$ G463A, MTHFR C677T, hOGG1 C326G, and ALDH2 genotypes are shown in Table 3. The Hardy-Weinberg test for the control group showed that the distributions of the five genotypes were in equilibrium.

As shown in Table 4 after adjusting for the potential confounders gender, age, school years, income per year, smoking index, alcohol drinking status, and family history of esophageal cancer, we found that polymorphism of the $A L D H 2$ genotype was associated with $\mathrm{BCH}$, ESCD, and ESCC. Compared to the ALDH 1*1 genotype, the $A L H D 2 * 2$ genotype was associated with significantly increased risks of $\mathrm{BCH}, \mathrm{ESCD}$, and ESCC (with the adjusted $\mathrm{OR}=4.15,95 \% \mathrm{CI}, 2.33-7.40$ for $\mathrm{BCH}$, OR $=4.54,95 \%$ CI 2.32-8.89 for ESCD, and OR $=3.38,95 \%$ CI 1.64-6.95 for ESCC). Furthermore, the TT genotype of MTHFR C677T increased the relative risk in the ESCC group, while the GG genotype of hOGG1 C326G increased the risk in the ESCD group.

Based on the values of $\mathrm{OR}_{\mathrm{G}}$, only the MTHFR C677T genotype $\left(\mathrm{OR}_{\mathrm{G}}=1.16 ; 95 \% \mathrm{CI}: 1.00-1.35\right)$ and $A L D H 2$ $\left(\mathrm{OR}_{\mathrm{G}}=1.52 ; 95 \% \mathrm{CI}: 1.30-1.77\right)$ genotype showed significant genetic association with the risk of carcinogenic progression of the esophagus.

Table 3 Distribution of CYP2E1, MPO, MTHFR and ALDH2 genotypes in the BCH, ESCD, ESCC and controls, $\mathbf{n}(\%)$

\begin{tabular}{|c|c|c|c|c|c|}
\hline Feature & $\mathrm{BCH}$ & ESCD & ESCC & Controls & $x^{2} \& P^{a}$ \\
\hline \multicolumn{6}{|c|}{ CYP2E1 G1259C } \\
\hline $\mathrm{C} 2 / \mathrm{C} 2$ & $4(1.5)$ & 0 & 0 & $11(4.5)$ & 1.519 \\
\hline $\mathrm{C} 1 / \mathrm{C} 2$ & $83(30.8)$ & $73(27.9)$ & 67(29.6) & $62(25.0)$ & $0.678 b$ \\
\hline C1/C1 & 183(67.7) & 189(72.1) & 159(70.4) & 173(70.5) & \\
\hline \multicolumn{6}{|l|}{ MPO G463A } \\
\hline $\mathrm{G} / \mathrm{G}$ & $221(81.8)$ & 234(89.2) & $175(77.4)$ & 191(77.8) & 15.942 \\
\hline$A / G$ & 49(18.2) & 28(10.8) & $44(19.4)$ & $52(21.2)$ & $0.001^{b}$ \\
\hline$A / A$ & 0 & 0 & $7(3.2)$ & $2(1.0)$ & \\
\hline \multicolumn{6}{|c|}{ hOGG1 C326G } \\
\hline $\mathrm{G} / \mathrm{G}$ & $43(15.9)$ & $26(10.1)$ & $13(5.9)$ & $26(10.4)$ & 24.003 \\
\hline$C / G$ & $123(45.7)$ & $160(60.9)$ & $126(55.9)$ & $123(50.0)$ & $<0.001$ \\
\hline $\mathrm{C} / \mathrm{C}$ & $104(38.4)$ & $76(29)$ & $86(38.2)$ & 97(39.6) & \\
\hline \multicolumn{6}{|c|}{ MTHFR C677T } \\
\hline $\mathrm{T} / \mathrm{T}$ & $45(16.7)$ & $85(32.4)$ & $64(28.4)$ & $58(23.6)$ & 20.705 \\
\hline $\mathrm{C} / \mathrm{T}$ & $113(41.9)$ & $82(31.3)$ & $85(37.5)$ & $97(39.4)$ & 0.002 \\
\hline C/C & $112(41.4)$ & $95(36.3)$ & $77(34.1)$ & $91(37.0)$ & \\
\hline \multicolumn{6}{|l|}{$A L D H 2$} \\
\hline $\mathrm{G} / \mathrm{G}\left(2^{*} 2\right)$ & $106(39.4)$ & $145(55.3)$ & $76(33.6)$ & $41(16.7)$ & 80.423 \\
\hline $\mathrm{A} / \mathrm{G}\left(1^{*} 2\right)$ & $134(49.5)$ & $85(32.5)$ & $129(57.1)$ & 164(66.6) & $<0.001$ \\
\hline $\mathrm{A} / \mathrm{A}(1 * 1)$ & $30(11.1)$ & $32(12.2)$ & $21(9.3)$ & $41(16.7)$ & \\
\hline
\end{tabular}

${ }^{\mathrm{a}} \mathrm{P}$ : Chi-square test was for proportions among the four groups. ${ }^{\mathrm{b}}$ : KruskalWallis $\mathrm{H}$ test. Abbreviations: $\mathrm{BCH}$, Basal cell hyperplasia; ESCD, esophageal squamous cell dysplasia; ESCC, Esophageal Squamous cell cancer. 
Table 4 Risk genotypes related to BCH, ESCD and ESCC in the multinomial logistic regression models ${ }^{a}$

\begin{tabular}{|c|c|c|c|c|}
\hline Factors & $\begin{array}{c}\mathrm{BCH} \\
\text { OR(95\%Cl) }\end{array}$ & $\begin{array}{c}\text { ESCD } \\
\text { OR( }(95 \% \mathrm{Cl})\end{array}$ & $\begin{array}{c}\text { ESCC } \\
\text { OR( } 95 \% \mathrm{Cl})\end{array}$ & $\mathrm{OR}_{\mathrm{G}}(95 \% \mathrm{Cl}) \#$ \\
\hline \multicolumn{5}{|l|}{ MTHFR C677T } \\
\hline$\pi$ & $0.91(0.59-1.40)$ & $0.78(0.48-1.28)$ & $1.85(1.02-3.34)$ & $1.16(1.00-1.35)$ \\
\hline$C T$ & $0.89(0.58-1.37)$ & $0.56(0.34-1.03)$ & $1.72(0.95-3.10)$ & \\
\hline TT\&TC & $0.90(0.62-1.32)$ & $0.66(0.43-1.12)$ & $1.71(1.01-2.91)$ & \\
\hline CC & 1.00 & 1.00 & 1.00 & \\
\hline \multicolumn{5}{|l|}{ MPO G463A } \\
\hline GG & $1.09(0.64-1.86)$ & $2.13(0.90-5.08)$ & $0.96(0.52-1.78)$ & $0.93(0.72-1.19)$ \\
\hline GA\&AA & 1.00 & 1.00 & 1.00 & \\
\hline \multicolumn{5}{|l|}{ CYP2E1 G1259C } \\
\hline$C 2 / C 2 \& C 1 / C 2$ & $1.15(0.64-2.09)$ & $0.79(0.38-1.62)$ & $1,01(0.43-2.33)$ & $0.94(0.77-1.14)$ \\
\hline $\mathrm{C} 1 / \mathrm{C} 1$ & 1.00 & 1.00 & 1.00 & \\
\hline \multicolumn{5}{|l|}{ hOGG1 C326G } \\
\hline GG & $1.56(0.71-3.43)$ & $1.23(0.46-3.26)$ & $0.50(0.14-1.81)$ & $1.00(0.85-1.78)$ \\
\hline GC & $1.10(0.66-1.86)$ & $2.33(1.24-4.36)$ & $1.45(0.72-2.92)$ & \\
\hline GG\&GC & 1.2990.73-1.97) & $2.08(1.14-3.76)$ & $1.23(0.63-2.40)$ & \\
\hline CC & 1.00 & 1.00 & 1.00 & \\
\hline \multicolumn{5}{|l|}{$\mathrm{ALDH} 2$} \\
\hline $2^{*} 2$ & $4.15(2.33-7.40)$ & $4.54(2.32-8.89)$ & $3.38(1.64-6.95)$ & $1.52(1.30-1.77)$ \\
\hline $1 * 2$ & $1.19(0.72-1.95)$ & $0.65(0.34-1.22)$ & $1.39(0.73-2.64)$ & \\
\hline $2 * 2 \& 1 * 2$ & $1.73(1.07-2.81)$ & $1.43(0.79-2.58)$ & $1.80(0.97-3.38)$ & \\
\hline $1 * 1$ & 1.00 & 1.00 & 1.00 & \\
\hline
\end{tabular}

a: Adjusted for age, sex, income, school year, smoking, drinking and family history of esophageal cancer. Abbreviations: BCH, Basal cell hyperplasia; ESCD, esophageal squamous cell dysplasia; ESCC, Esophageal Squamous cell cancer; OR $\mathrm{R}_{\mathrm{G}}$ generalized odds ratio.

\#: OR $\mathrm{G}_{\mathrm{G}}$ calculated by the software "ORGGASMA" of the web site htpp://biomath.med.uth.gr.(note:: added 0.5 to zero frequency of cell).

\section{Combing two-susceptibility genotypes analysis}

Subjects with either homozygous or heterozygous variant alleles $(2 * 2$ or $1 * 2)$ of $A L D H 2$ had increased risk of developing $\mathrm{BCH}, \mathrm{ESCD}$, and ESCC compared to those who had wild type $A L D H 2$ (Table 4). Furthermore, TT and CT genotypes of MTHFR C677T were found to enhanced susceptibility to ESCC compared to the CC genotype.

The frequencies of the various combinations of the susceptible genotypes of ALDH 2 and MTHFR C677T genes were calculated and analyzed for their associated risks of diseases (Tables 5 and 6). The OR values for the associations of the combined susceptibility genotypes with esophageal lesions was significantly higher than for the individual genotypes (Table 6). For example, after adjusting for the aforementioned seven potential confounders, the combinations of $A L D H 22 \% 2 / 1 * 2$ and $M T H F R$ TT/TC genotypes were associated with significantly increased risks for $\mathrm{BCH}$, ESCD, and ESCC compared to patients with the $1^{*} 1 A L D H 2$ and CC MTHFR C677T genotype. The ORs (95\%CI) were 4.03(2.14-7.57) for $\mathrm{BCH}, 3.70(1.74-7.87)$ for $\mathrm{ESCD}$, and 8.72(3.24-23.48) for ESCC. Furthermore, the $\mathrm{OR}_{\mathrm{G}}$ of the two combined genotypes was 1.83(95\%CI: 1.55-2.16), indicating a significant genetic association with the risk of carcinogenic progression in the esophagus.

\section{Discussion}

Feicheng County has a high incidence of esophageal cancer compared to the rest of China. Worldwide mortality rates have decreased from 75.82 per 100,000 in 1970-1974 to 57.22 per 100,000 in $2000-2004$ [25]. In the present study, we demonstrate that specific allelic combination significantly increased the risk for esophageal cancer (by as much as 8 -fold). While reproducibility of studies linking genotype to disease risk is often problematic, there are several strengths of this study. First, the subjects in the study were diagnosed by biopsy, so misclassification bias was very low. Our DNA collection method avoided biases that may arise from single-center or multi-center collection. Furthermore, several steps were taken to ensure high quality and repeatability of

Table 5 Distribution of subjects with the number of susceptibility of the combination of the ALDH2 and MTHFR genes in the four groups

\begin{tabular}{llcccc}
\hline ALDH2 & MTHFR & ESCC $\mathbf{n}, \%$ & ESCD $\mathbf{n}, \%$ & BCH $\mathbf{n}, \%$ & Normal $\mathbf{n} \%$ \\
\hline $2^{*} 2 / 1^{*} 2$ & TC/TT & $163(72.1)$ & $138(52.7)$ & $150(55.5)$ & $100(40.7)$ \\
$2^{*} 2 / 1^{*} 2$ & CC & $38(16.8)$ & $84(32.1)$ & $80(29.6)$ & $54(22.0)$ \\
$1^{* 1}$ & TC/TT & $17(7.5)$ & $26(9.9)$ & $25(9.3)$ & $52(21.1)$ \\
$1^{* 1}$ & CC & $7(3.1)$ & $14(5.3)$ & $15(5.6)$ & $40(16.2)$ \\
\hline \multicolumn{7}{r}{ Total } & $226(100.0)$ & $262(100.0)$ & $270(100.0)$ & $246(100.0)$ \\
\hline
\end{tabular}


Table 6 ORs $(95 \% \mathrm{Cl})$ of the susceptibility genotypes of the combination of the ALDH2 and MTHFR genes related to lesions of esophagus ${ }^{a}$

\begin{tabular}{|c|c|c|c|c|c|c|c|}
\hline \multirow[b]{2}{*}{ ALDH2 } & \multirow[b]{2}{*}{ MTHFR } & \multicolumn{3}{|c|}{ Crude OR(95\%Cl) } & \multicolumn{3}{|c|}{ Adjusted OR(95\%Cl) } \\
\hline & & $\mathrm{BCH}$ & ESCD & ESCC & $\mathrm{BCH}$ & ESCD & ESCC \\
\hline $2 * 2 / 1 * 2$ & $\mathrm{TC} / \mathrm{TT}$ & $\begin{array}{c}4.00 \\
(2.28-7.17)\end{array}$ & $\begin{array}{c}3.92 \\
(2.06-8.11)\end{array}$ & $\begin{array}{c}9.31 \\
(3.81-23.12)\end{array}$ & $\begin{array}{c}4.03 \\
(2.14-7.57)\end{array}$ & $\begin{array}{c}3.70 \\
(1.74-7.87)\end{array}$ & $\begin{array}{c}8.72 \\
(3.24-23.48)\end{array}$ \\
\hline $2 * 2 / 1 * 2$ & CC & $3.95(2.16-7.42)$ & $\begin{array}{c}4.44 \\
(2.25-9.60)\end{array}$ & $\begin{array}{c}4.02 \\
(1.58-10.94)\end{array}$ & $\begin{array}{c}4.21 \\
(2.14-8.29)\end{array}$ & $\begin{array}{c}4.68 \\
(2.11-10.38)\end{array}$ & $\begin{array}{c}4.45 \\
(1.54-12.87)\end{array}$ \\
\hline $1 * 1$ & $\mathrm{TC} / \mathrm{TT}$ & $\begin{array}{c}1.37 \\
(0.65-2.50)\end{array}$ & $\begin{array}{c}1.43 \\
(0.67-3.29)\end{array}$ & $\begin{array}{c}1.87 \\
(0.68-5.45)\end{array}$ & $\begin{array}{c}1.18 \\
(0.56-2.49)\end{array}$ & $\begin{array}{c}1.23 \\
(0.51-2.95)\end{array}$ & $\begin{array}{c}1.80 \\
(0.57-5.68)\end{array}$ \\
\hline $1 * 1$ & CC & 1.00 & 1.00 & 1.00 & 1.00 & 1.00 & 1.00 \\
\hline
\end{tabular}

a: Adjusted for age, sex, income, school year, smoking, drinking and family history of esophageal cancer. Abbreviations: BCH, basal cell hyperplasia; ESCD, esophageal squamous cell dysplasia; ESCC, Esophageal Squamous cell cancer.

results. These included initial DNA sequencing of SNP regions to prove the reliability, blinding of the operator to the case-control status of samples to reduce observer bias, and simultaneous analysis of case and control samples to avoid differential misclassification. Moreover, the allele frequencies reported among normal controls in this study were similar to those reported in previous studies of Chinese subjects. In sum, these controls indicated that our findings have high validity and reliability.

In the present study, we found that the $A L D H 2$ genotype was associated with $\mathrm{BCH}, \mathrm{ESCD}$, and ESCC, the main stages of carcinogenic transition in the esophagus. Acetaldehyde is formed by the oxidation of ethanol by alcohol dehydrogenase $(A D H)$, and is eliminated by aldehyde dehydrogenase $(A L D H)$. The $A L D H 2$ gene carries two alleles, $A L D H 2 * 1$ and $A L D H 2 * 2$, with different kinetic properties and distinct distributions among ethnicities $[23,26]$. The $A L D H 2 * 2$ allele is found at a frequency of only $50 \%$ in Orientals, while the $A L D H 2 * 1$ allele is more predominant in Caucasians [26]. The $A L D H 2 * 2$ allele codes for an inactive $A L D H 2$, and is closely associated with alcohol related cancers in the upper aerodigestive tract [27-29]. The accumulation of acetaldehyde plays a protective role against excessive alcohol consumption as it causes unpleasant reactions, including "Oriental facial flushing" and other symptoms due to alcohol sensitivity, such as headache, nausea, vomiting, tachycardia, hypotension, and sleepiness [30]. Essentially, a person harboring the $A L D H 2 * 2$ allele may not become a heavy drinker. Indeed, genetic epidemiologic studies have indicated that the ALDH2*2 allele inhibits the development of alcoholism. However, many studies demonstrated that patients harboring $A L D H 2 * 2$ allele who are heavy drinkers were at increased risk of ESCC. It is unknown why patients harboring the $A L D H 2 * 2$ allele became heavy drinkers despite the unpleasant reaction to acetaldehyde [28-31].

In the present study, heavy drinkers with $A L D H 2 \% 2 /$ $2 * 2, A L D H 2 * 1 / 2 * 2$, and $A L D H 2 * 1 / 2 * 1$ genotypes comprised $3.9 \%, 25.5 \%$, and $14.7 \%$ of the cancer group, and
$2.5 \%, 20.0 \%$, and $0.8 \%$ of the control group, respectively. It is clear that persons harboring the $A L D H 2 * 2 / 2 * 2$ genotype are less likely to be heavy drinkers than those harboring the $A L D H 2 * 1 / 2 * 2$ or $A L D H 2 * 1 / 2 * 1$ genotypes. Aside from the increased sensitivity of alcohol-induced nausea, this may reflect a very low level of alcohol consumption in Feicheng County, where living standards are relatively low and the majority of farmers cannot afford alcoholic beverages [32,33].

The TT genotype of the MTHFR gene had a significantly positive association with ESCC (OR $=1.85,95 \%$ CI 1.02-3.34) but not with $\mathrm{BCH}$ or ESCD. There was also a significant association between esophageal cancer and the MTHFR TT genotype with which the patient was also a heavy smoker. Associational studies linking polymorphisms of the MTHFR C677T genotype with ESCC risk have yielded inconsistent result. A meta-analysis of studies examined the association of the MTHFR C667T polymorphism with risk of esophageal cancer [34].

The association between esophageal cancer and MTHFR enzyme activity is most likely related to the metabolism of folic acid, as risk of esophageal cancer depends on the status of folic acid intake. When folic acid intake is sufficient, individuals with the MTHFR CT or TT genotypes may actually have a decreased risk of esophageal lesions because the lower MTHFR activity of the 677TT allele may lead to an elevation in 5, 10methylenetetrahydrofolate, facilitating DNA synthesis. In contrast, both impaired DNA methylation and DNA synthesis/repair may become the primary mechanisms of carcinogenesis in the presence of low folic acid intake [16,35-37]. However, the TT genotype was not related to $\mathrm{BCH}$ or ESCD, suggesting a weaker or absent linkage.

We present evidence that two susceptibility genes, ALDH2*2 and MTHFR 677T, contribute to the process of esophageal carcinogenesis. The combination of the two high-risk genotypes $2 * 2 / 1 * 2$ of $A L D H 2$ and TT/TC of MTHFR C677T resulted in a 4-fold higher risk of developing $\mathrm{BCH}$, a 3.7 -fold increased risk of ESCD, and a 
8.72 times higher ESSC risk. The ALDH 2 and MTHFR C677T genes showed a significant association with ESCC in our population.

In contrast to $A L D H 2$ and MTHFR, polymorphisms of CYP2E1 G1259C, MPO G463A, and hOGG1 C326G genes were not associated with $\mathrm{BCH}$, ESCD, or ESCC risk in this study. These negative results may be attributable to the fact that the study population came from the same community where residents share a similar life style and diet. This homogeneity may cause an overmatch, such that the association of these two metabolic enzyme genes (CYP2E1, MPO) and one repair gene ( $h O G G 1$ ) with lesions of the esophagus cannot be demonstrated or is too low to estimate. In addition, because these alleles were associated with smaller ORs $(<2.0)$ for risk of the diseases, this effects would not be detected due to an allele null frequency less than 0.10. The sample size, therefore, may not have been large enough to detect an association.

\section{Conclusion}

The $A L D H 2 * 2$ and MTHFR $677 \mathrm{~T}$ alleles were associated with higher susceptibility to esophageal cancer. Compared with the $A L D H 1 * 1$ genotype, the ALHD 2*2 genotype was associated with significantly increased risks for $\mathrm{BCH}$, ESCD, and ESCC, while the TT genotype of MTHFR C677T increased the risk of ESCC. The generalized odds ratio analysis confirmed these findings. Further analysis revealed that the combination of these high-risk genotypes (2*2/1*2 of ALDH 2 and TT/TC of MTHFR C677T) significantly increased susceptibility for $\mathrm{BCH}, \mathrm{ESCD}$, and ESSC (by 4.0, 3.7 and 8.72 fold, respectively). The $\mathrm{OR}_{\mathrm{G}}$ of the two genotypes combined was $1.83(95 \% \mathrm{CI}$ : $1.55-2.16)$, indicating a significant genetic association between this combined genotype and cancer of the esophagus.

\section{Abbreviations \\ BCH: Basal cell hyperplasia; ESCD: Esophageal squamous cell dysplasia; ESCC: Esophageal squamous cell cancer; LGD: Low-grade dysplasia; HGD: High- grade dysplasia; ALDH2: Aldehyde dehydrogenase-2; MTFHR: Methylenetetrahydrofolate reductase; CYP2E1: Cytochrome P450 2E1; MPO: Myeloperoxidase; hOGG1: Human 8-oxoguanine glycosylase 1; $\mathrm{OR}_{\mathrm{G}}$ : generalized odds ratio.}

\section{Acknowledgements}

We are grateful to Prof. Qing-shan Qu (Department of Environmental Medicine, New York University School of Medicine) for review and check the manuscript. This study was supported by the Project of Natural Science Foundation of China(No.30571601)and the 2004 Key Special Project of Scientific and Technological Development in Shandong Province, China (No. 2004GG1108039)

\footnotetext{
Author details

${ }^{1}$ The Key Laboratory of Cardiovascular Remodeling and Function Research, Chinese Ministry of Education and Chinese Ministry of Health, Qilu Hospital of Shandong University, 107\# Wenhuaxi Road, Jinan, 250012, China. ${ }^{2}$ Department of Hematology of Tumor Center, Qilu Hospital of Shandong University, 107\# Wenhuaxi Road, Jinan, 250012, China. ${ }^{3}$ Department of Epidemiology, College of Public Health of Shandong University, 104\#
}

Wenhuaxi Road, Jinan, 250012, China. ${ }^{4}$ Department of Epidemiology, Institute of Basic Medicine of Shandong Academy of Medical Sciences, 18877\# Jingshi Road, Jinan, 250062,China. ${ }^{5}$ Department of Statistics, School of Economics, Shandong University, 27\# Shada Nanlu, Jinan, 250100,China. ${ }^{6}$ Department of Infectious Disease of Shandong Center for Disease Control and Prevention, 72\# Jingshi Road, Jinan, 250014, China. ${ }^{7}$ Department of Epidemiology, College of Public Health of Southwestern University, 16\# Renminnan Road, Chengdou, 610041, China.

\section{Authors' contributions}

QDL, HL and MSW carried out study design, literature research, experimental studies, data acquisition, statistical analysis and manuscript preparation (they made the same contribution to the study). TYD, ZYZ, QXF, FYY and QHL participated in literature research, data analysis and manuscript editing. All authors read and approved the final manuscript.

\section{Competing interests}

The authors declare that they have no competing interests.

Received: 2 February 2011 Accepted: 14 June 2011

Published: 14 June 2011

\section{References}

1. Wang LD, Zhou Q, Yang CS: Esophageal and gastric cardia epithelial cell proliferation in northern Chinese subjects living in a high-incidence area. J Cell Biochem Suppls 1997, 28/29:159-165.

2. Shimizu M, Ban S, Odze RD: Squamous Dysplasia and Other Precursor Lesions Related to Esophageal Squamous Cell Carcinoma. Gastroenterol Clin N Am 2007, 36:797-811.

3. Kuwano H, Watanabe M, Sadanaga N, Ikebe M, Mori M, Sugimachi K: Squamous epithelial dysplasia associated with squamous cell carcinoma of the esophagus. Cancer Lett 1993, 72:141-147.

4. Schlemper RJ, Dawsey SM, Itabashi M, Iwashita A, Kato Y, Koike M, Lewin KJ, Riddell RH, Shimoda T, Sipponen P, Stolte M, Watanabe H: Differences in diagnostic criteria for esophageal squamous cell carcinoma between Japanese and Western pathologists. Cancer 2000, 88:996-1006.

5. Rubio CA, Liu FS, Zhao HZ: Histological classification of intraepithelial neoplasias and microinvasive squamous carcinoma of the esophagus. Am J Surg Pathol 1989, 13:685-690.

6. Qiu SL, Yang GR: Precursor lesions of esophageal cancer in high-risk populations in Henan Province, China. Cancer 1988, 62:551-557.

7. Wang LD, Yang HH, Fan ZM, Lü XD, Wang JK, Liu XL, Sun Z, Jiang YN, He X, Zhou Q: Cytological screening and 15 years' follow-up (1986-2001) for early esophageal squamous cell carcinoma and precancerous lesions in a high-risk population in Anyang County, Henan Province, Northern China. Cancer Detect Prev 2005, 29:317-322.

8. Dawsey SM, Lewin KJ, Wang GQ, Liu FS, Nieberg RK, Yu Y, Li JY, Blot WJ, Li B, Taylor PR: Squamouse esophageal histology and subsequent risk of squamous cell carcinoma of the esophagus. A prospective follow-up study from Linxian, China. Cancer 1994, 74:1686-1692.

9. Wang GQ: Clinical preventive strategies to decrease incidence and death rates of esophageal cancer in high-risk areas. Zhonghua Zhongliu Zazhi 1999, 21:223.

10. Wang LD, Zhou Q, Feng CW, Liu B, Qi YJ, Zhang YR: Intervention and follow-up on human esophageal precancerous lesions in Henan, northern China, a high-incidence area for esophageal cancer. Gan to Kagaku Ryoho 2002, 29(Suppl 1):159-172.

11. Yang GR, Oiu SL: Endoscopie surveys in high-risk populations for esophageal cancer in China with special reference to precursors of esophageal cancer. Endoscopy 1987, 19:91-95.

12. Yang CX, Matsuo K, Ito H, Hirose K, Wakai K, Saito T, Shinoda M, Hatooka S, Mizutani K, Tajima K: Esophageal cancer risk by ALDH2 and ADH2 polymorphisms and alcohol consumption: exploration of geneenvironment and gene-gene interactions. Asian Pac J Cancer Prev 2005, 6:56-62.

13. Nishimura FT, Kimura Y, Abe S, Fukunaga T, Saijoh K: Effect of -361 ALDH2*1/ALDH2*2 polymorphism of aldehyde dehydrogenase-2 gene on alcohol metabolism and its expression in human peripheral blood leukocytes. Nihon Arukoru Yakubutsu Igakkai Zasshi 2006, 41:108-119.

14. Yokoyama A, Kato H, Yokoyama T, Igaki H, Tsujinaka T, Muto M, Omori T, Kumagai $Y$, Yokoyama M, Watanabe H: Esophageal squamous cell 
carcinoma and aldehyde dehydrogenase-2 genotypes in Japanese females. Alcohol Clin Exp Res 2006, 30:491-500.

15. Zhang J, Zotz RB, Li Y, Wang R, Kiel S, Schulz WA, Wen D, Chen Z, Zhang L, Wang S, Gabbert HE, Sarbia M: Methylenetetrahydrofolate reductase C677T polymorphism and predisposition towards esophageal squamous cell carcinoma in a German Caucasian and a northern Chinese population. J Cancer Res Clin Oncol 2004, 130:574-580.

16. Song C, Xing D, Tan W, Wei Q and Lin D: Methylenetetrahydrofolate reductase polymorphisms increase risk of esophageal squamous cell carcinoma in a Chinese population. Cancer Res 2001, 61:3272-3275.

17. Yang CX, Matsuo K, Ito H, Shinoda M, Hatooka S, Hirose K, Wakai K, Saito T, Suzuki T, Maeda T, Tajima K: Gene-environment interactions between alcohol drinking and the MTHFR C677T polymorphism impact on esophageal cancer risk: results of a case-control study in Japan. Carcinogenesis 2005, 26:1285-1290.

18. Liu R, Yin LH, Pu YP: Association of combined CYP2E1 gene polymorphism with the risk for esophageal squamous cell carcinoma in Huaian population, China. Chinese Medical Journal 2007, 120:1797-1802.

19. Xing D, Tan W, Lin D: Genetic polymorphisms and susceptibility to esophageal cancer among Chinese population (review). Oncol Rep 2003, 10:1615-1623

20. Cascorbi I, Henning S, Brockmöller J, Gephart J, Meisel C, Müller JM, Loddenkemper $\mathrm{R}$, Roots I: Substantially reduced risk of cancer of the aero digestive tract in subjects with variant-463A of the myeloperoxidase gene. Cancer Res 2000, 60:644-649.

21. Matsuo K, Hamajima N, Shinoda M, Hatooka S, Inoue M, Takezaki T, Onda H, Tajima K: Possible risk reduction in esophageal cancer associated with MPO -463a allele. Journal of Epidemiology 2001, 11:109-114.

22. Xing DY, Tan W, Song N, Lin DX: Ser 326 Cys polymorphism in hOGG1 gene and risk of esophageal cancer in a Chinese population. Int J Cancer 2001, 95:140-143.

23. Yoshida A, Huang Y, Ikawa M: Molecular abnormality of an inactive aldehyde dehydrogenase variant commonly found in Orientals. Proc Natl Acad Sci USA 1984, 81:258-261.

24. Zintzaras $\mathrm{E}$ : The generalized odds ratio as a measure of genetic risk effect in the analysis and meta-analysis of association studies. Stat Appl Genet Mol Biol 2010, 9(1), Article21.

25. Zhao DI, Wang Jl, Zhou YZh, Li HQ: Cancer incidence during 2000-2004 year of Feicheng rural area in Shandong, China. J cancer Prev Treat 2005, 12:891-894.

26. Harada S, Misawa S, Agarwal DP, Goedde HW: Liver alcohol dehydrogenase and aldehyde dehydrogenase in the Japanese: Isozyme variation and its possible role in alcohol intoxication. Am J Hum Genet 1980, 32:8-15.

27. Yokoyama A, Muramatsu T, Ohmori T, Makuuchi H, Higuchi S, Matsushita S, Yoshino K, Maruyama K, Nakano M, Ishii H: Multiple primary esophageal and concurrent upper aerodigestive tract cancer and the aldehyde dehydrogenase-2 genotype of Japanese alcoholics. Cancer 1996, 77:1986-1990

28. Hori H, Kawano T, Endo M, Yuasa Y: Genetic polymorphisms of tobaccoand alcohol-related metabolizing enzymes and human esophageal squamous cell carcinoma susceptibility. J Clin Gastroenterol 1997, 25:568-575.

29. Nomura T, Noda H, Shibahara T, Yokoyama A, Muramatsu T, Ohmori T: Aldehyde dehydrogenase 2 and glutathione S-transferase M1 polymorphism in relation to the risk for oral cancer in Japanese drinkers. Oral Oncol 2000, 36:42-46.

30. Sun F, Tsuritani I, Honda R, Ma ZY, Yamada Y: Association of genetic polymorphisms of alcohol-metabolizing enzymes with excessive alcohol consumption in Japanese men. Hum Genet 1999, 105:295-300.

31. Muto M, Nakane M, Hitomi Y, Yoshida S, Sasaki S, Ohtsu A, Yoshida S, Ebihara S, Esumi $\mathrm{H}$ : Association between aldehyde dehydrogenase gene polymorphisms and the phenomenon of field cancerization in patients with head and neck cancer. Carcinogenesis 2002, 23(10 pp):1759-1765.

32. Matsuo K, Hamajima N, Shinoda M, Hatooka S, Inoue M, Takezaki T, Tajima K: Gene-environment interaction between an aldehyde dehydrogenase-2 (ALDH2) polymorphism and alcohol consumption for the risk of esophageal cancer. Carcinogenesis 2001, 22:913-916.

33. Ding JH, Li SP, Cao HX, Wu JZ, Gao CM, Su P, Liu YT, Zhou JN, Chang J, Yao GH: Polymorphisms of alcohol dehydrogenase-2 and aldehyde dehydrogenase-2 and esophageal cancer risk in Southeast Chinese males. World J Gastroenterol 2009, 15:2395-2400.

34. Yoshihara M, Tanaka S, Chayama K: Genetic polymorphisms and esophageal cancer risk. Int J Cancer 2007, 121:1643-1658.

35. Bailey LB, Gregory JF III: Polymorphisms of methylenetetrahydrofolate reductase and other enzymes: metabolic significance, risks and impact on folate requirement. J Nutr 1999, 129:919-922.

36. Song C, Xing D, Tan W, Wei Q and Lin D: Methylenetetrahydrofolate reductase polymorphisms increase risk of esophageal squamous cell carcinoma in a Chinese population. Cancer Res 2001, 61:3272-3275.

37. Stolzenberg-Solomon RZ, Qiao YL, Abnet CC, Ratnasinghe DL, Dawsey SM Dong ZW, Taylor PR, Mark SD: Esophageal and gastric cardia cancer risk and folate- and vitamin B(12)-related polymorphisms in Linxian, China. Cancer Epidemiol Biomarkers Prev 2003, 12:1222-226.

\section{Pre-publication history}

The pre-publication history for this paper can be accessed here: http://www.biomedcentral.com/1471-230X/11/74/prepub

doi:10.1186/1471-230X-11-74

Cite this article as: Li et al:: Multi-susceptibility genes associated with the risk of the development stages of esophageal squamous cell cancer in Feicheng County. BMC Gastroenterology 2011 11:74.

\section{Submit your next manuscript to BioMed Central and take full advantage of:}

- Convenient online submission

- Thorough peer review

- No space constraints or color figure charges

- Immediate publication on acceptance

- Inclusion in PubMed, CAS, Scopus and Google Scholar

- Research which is freely available for redistribution

Submit your manuscript at www.biomedcentral.com/submit
Biomed Central 